\title{
Recognition and quantification of myocardial injury by means of plasma enzyme and isoenzyme activities after cardiac surgery
}

\author{
A. VAN DER LAARSE, H. A. DAVIDS, L. HOLLAAR, \\ E. J. M. VAN DER VALK, S. A. G. J. WITTEVEEN, AND W. TH. HERMENS \\ From the Department of Cardiology, University Hospital Leiden, Leiden, and the Department of \\ Biophysics, Biomedical Centre, State University of Limburg, Maastricht, Netherlands
}

SUMMARY Serial plasma enzyme determinations were carried out in 32 patients who underwent cardiac surgery with the aid of extracorporeal circulation. Plasma creatine kinase (CK), the cardiospecific isoenzyme of $\mathrm{CK}(\mathrm{CKMB})$, and alpha-hydroxybutyrate dehydrogenase $(\mathrm{HBDH})$ were determined from the onset of surgery up to 100 to 120 hours after operation. From the plasma enzyme activities, the total amount of enzyme released by the injured heart into the circulation could be calculated using mathematical equations solved numerically by means of a computer. The calculated amount of $C K, C K M B$, and HBDH released by the heart correlated well with (1) postoperative mortality, and (2) peak activities of the respective enzymes. The calculated amount of any of the 3 enzymes released showed poor or no correlation with (1) electrocardiographic criteria of myocardial infarction, (2) duration of cardiopulmonary bypass, and (3) duration of total aortic cross-clamping.

This study shows that the extent of myocardial injury after surgery can be assessed quantitatively using the calculated amounts of enzyme released, as well as using peak plasma activities of CKMB and HBDH.

Cardiac surgery using extracorporeal circulation may be complicated by the per- and postoperative development of myocardial infarction. The diagnosis of myocardial infarction is generally based on electrocardiographic criteria of which the most specific, though not very sensitive, is the appearance of $Q$ waves (Brewer et al., 1973; Espinoza et al., 1974; Rose et al., 1974). However, in a number of cases the postoperative occurrence of ventricular conduction disturbances and arrhythmias such as bundle-branch block, complete heart block, or ventricular tachycardia hampers the detection of new $Q$ waves.

Rises in the plasma enzymes aspartate aminotransferase (AST, EC 2.6.1.1), creatine kinase (CK, EC 2.7.3.2), and lactate dehydrogenase (LDH, EC 1.1.1.27) are commonly used for the diagnosis of acute myocardial infarction. This method is sensitive but non-specific, as enzymes can leak into the circulation from sources other than

Received for publication 27 July 1978 the heart. Examples include SGOT (AST) from the liver in the presence of congestive heart failure, $\mathrm{LDH}$ from erythrocytes when there is haemolysis, and CK from skeletal muscle after muscle trauma.

The introduction of isoenzyme determinations has improved the diagnostic value of enzyme tests. The cardiospecific isoenzyme of CK (CKMB) has been used successfully for the detection of acute myocardial infarction in patients in coronary care units (Konttinen and Somer, 1972; Roe et al. 1972; Roberts et al., 1975a) and in patients undergoing aortocoronary bypass surgery (Dixon et al., 1973; Oldham et al., 1973; Pyle et al., 1976; Warren et al., 1977). Likewise the 'heart' fraction of LDH (LDH-1) has been proved to be valuable in the detection of acute myocardial infarction postoperatively (Codd et al., 1975; Mohiuddin et al., 1976; Codd et al., 1977).

In the present study $\mathrm{CK}, \mathrm{CKMB}$, and alphahydroxybutyrate dehydrogenase $(\mathrm{HBDH}$, an accepted method of assessing the sum of LDH-1 and LDH-2 activities) were determined in serial plasma 
Table 1 Clinical data of 3 groups of patients: (a) coronary artery bypass surgery, (b) aortic valve replacement, and (c) mitral valve replacement

\begin{tabular}{lccc}
\hline & $\begin{array}{l}\text { Coronary artery } \\
\text { bypass surgery }\end{array}$ & $\begin{array}{l}\text { Aortic valve } \\
\text { replacement }\end{array}$ & $\begin{array}{c}\text { Mitral valve } \\
\text { replacement }\end{array}$ \\
\hline No. of patients & 15 & 10 & 7 \\
Mean age (range) (y) & $50 \cdot 5(35-62)$ & $46.5(22-69)$ & $58 \cdot 0(46-68)$ \\
Sex & $12 \mathrm{M}, 3 \mathrm{~F}$ & $8 \mathrm{M}, 2 \mathrm{~F}$ & $2 \mathrm{M}, 5 \mathrm{~F}$ \\
Mean no. of grafts (range) & $1 \cdot 9(1-3)$ & & \\
Preoperative functional class & 1 & & \\
(NYHA) II & 13 & 4 & 5 \\
$\quad$ III & 1 & 0 & $119 \cdot 6 \pm 37 \cdot 6$ \\
Cardiopulmonary bypass time (mean \pm SD) (min) & $118 \cdot 0 \pm 50 \cdot 4$ & $156 \cdot 4 \pm 66 \cdot 8$ & $26 \cdot 1 \pm 17 \cdot 8$ \\
Aortic cross-clamp time (mean \pm SD) (min) & $34 \cdot 3 \pm 15 \cdot 8$ & $23 \cdot 2 \pm 13 \cdot 1$ & 0 \\
Electrocardiographic evidence of acute myocardial infarction & 4 & 2 & 0 \\
Mortality (within a week postoperatively) & 2 & 1 & \\
\hline
\end{tabular}

samples for a period of 5 days in patients treated surgically for coronary artery bypass grafts or valvular replacement. From the activity curves of the plasma enzymes, the total amount per litre plasma (A) of CK, CKMB, and $\mathrm{HBDH}$ released by the heart into the circulation postoperatively could be calculated using a method published earlier (Witteveen et al., 1975), which was slightly modified and in this study also applied to CKMB. The present study investigates the relation of the calculated A values with type of operation, postoperative mortality, electrocardiographic criteria of myocardial infarction, peak activity of plasma $\mathrm{CK}, \mathrm{CKMB}$, and $\mathrm{HBDH}$, and duration of cardiopulmonary bypass and aortic cross-clamping.

\section{Subjects and methods}

\section{PATIENTS}

Thirty-two patients are included in this study. Table 1 shows the clinical data. Three groups are distinguished according to the kind of operation: aortocoronary bypass grafting (15 patients), aortic valve replacement (10 patients), and mitral valve replacement ( 7 patients).

\section{METHODS}

All operations were performed with standard cardiopulmonary bypass techniques. Selective coronary perfusion was used in the valvular surgery groups. Mild systemic hypothermia of 28$30^{\circ} \mathrm{C}$ was used in all cases, together with topical myocardial cooling with iced saline. The pulmonary bypass system was primed with lactated Ringer solution with dextrose $(5 \%)$ and albumin, lowering the haematocrit from an average of 41.9 (range 50 to 33 ) to an average of $27 \cdot 2$ (range 34 to 21 ).

Defibrillation was effected by DC countershock of $50 \mathrm{~J}$ when necessary during rewarming. Duration of cardiopulmonary bypass and aortic crossclamping is shown in Table 1.
A standard 12 lead electrocardiogram was recorded before operation and repeated at least once daily after operation. The only electrocardiographic criterion to assess myocardial infarction was the appearance of $Q$ waves of $0.04 \mathrm{~s}$ duration or more (Brewer et al., 1973; Espinoza et al., 1974).

Ventricular conduction disturbances, such as bundle-branch block, total heart block, or severe ST-T segment changes, were considered as symptoms of acute ischaemic injury only (Codd et al., 1975; Hultgren et al., 1977).

\section{ENZYME ASSAYS}

Venous blood samples were taken before the first incision, immediately after termination of cardiopulmonary bypass, and subsequently every 6 hours for 100 to 120 hours. After the addition of $0.2 \mathrm{ml}$ 20 per cent trisodium citrate each $10 \mathrm{ml}$ sample was centrifuged at $1174 \mathrm{~g}$ for 10 minutes to remove blood cells. Thereafter the samples were stored at $-20^{\circ} \mathrm{C}$ until they were assayed for CK, CKMB, and HBDH. CK was assayed with creatine phosphate as a substrate (Oliver, 1955) using a testkit (Baker). The isoenzymes of CK were separated by ion-exchange chromatography on DEAESephadex into the 3 isoenzyme fractions: CKMM, CKMB, and CKBB (Pharmacia) (Mercer and Varat, 1975). HBDH was assayed with alphaketobutyrate as a substrate (Rosalki and Wilkinson, 1960) using a testkit (Boehringer). Enzyme activities were expressed in units $(U)$ per litre, in which $1 \mathrm{U}$ of enzyme catalyses the conversion of $1 \mu \mathrm{mol}$ substrate per minute at $25^{\circ} \mathrm{C}$.

\section{MATHEMATICAL ANALYSIS OF ENZYME}

ACTIVITY DATA

By following the plasma enzyme levels sequentially one can calculate the amount of enzyme released from the infarcted or damaged area into the circulation. The quantity of enzyme released per litre of plasma during the first 24 hours after operation 
is denoted as A. The restriction to 24 hours for the calculated quantity of enzyme released is discussed below. Previously this quantity was indicated by $Q$ (Witteveen et al., 1975), but in order to avoid confusion with the electrocardiographic $Q$ the no longer expressed in terms of grams of destroyed tissue since the quantity of enzyme released per litre of plasma is a better clinical index (Norris et al., 1975).

The calculation and the mathematical model used for the calculation are described in detail elsewhere (Witteveen et al., 1975). Briefly, the model is composed of two compartments, an intravascular space (volume $V_{i}$ ), and an extravascular space (volume $\mathrm{V}_{\mathrm{e}}$ ). Enzymes diffuse from one compartment to another with a permeability constant $P$ and are eliminated from the plasma with a certain disappearance constant $k$. Using these indices, the area into 1 litre of plasma (U/1) can be calculated.

The period of observation was too short to obtain reliable values for the apparent disappearance rate of $\mathrm{HBDH}$ in individual cases, so a fixed mean value of $0.012 / \mathrm{h}$ was used (Witteveen et al., 1975). In order to preserve comparability of results obtained for different enzymes, the same procedure was used for $C K$ and $C K M B$, using the mean values of $0.046 / \mathrm{h}$ and $0.096 / \mathrm{h}$, respectively, as determined for the total group of patients.

\section{STATISTICAL METHODS}

Statistical significance of differences between means was calculated using Student's t test for small samples. Linear regression analysis was employed to detect whether a linear correlation existed between pairs of values of two variables. Where necessary former $Q$ is replaced by $A$ in the present study. $A$ is total amount of enzyme (A) released by the infarcted

equations were used which allow for errors in both variables.

\section{Results}

Postoperative occurrence of myocardial infarction diagnosed on the basis of the development of $Q$ waves was observed in 4 of 15 patients who received aortocoronary bypass grafts $(27 \%)$ and in 2 of 17 patients with valvular replacement (12\%).

Mortality during surgery and in the postoperative period of 1 week was 2 of 15 patients in the coronary bypass group (13\%) and 1 of 17 patients in the valvular replacement group (6\%) (Table 1). At necropsy these hearts showed definite evidence of recent myocardial infarction, confirming the electrocardiographic diagnosis made during life.

The Figure shows the $A_{\mathrm{CK}}, A_{\mathrm{CKMB}}$, and $A_{\mathrm{HBDH}}$ in the 3 groups of patients. The mean $A$ values and the standard errors of the mean are listed in Table 2. The mitral valve replacement group shows significantly lower release of CK $(P<0.05)$ than the aortic valve replacement group.

Linear regression analysis was performed on the values of $A_{\text {CKMB }}$ which is known to be cardiospecific,

Table 2 Calculated total enzyme release per litre plasma $(A$, in $U / l)$ of $C K, C K M B$, and $H B D H$ in 3 groups of patients

\begin{tabular}{llll}
\hline & $\begin{array}{l}\text { Coronary artery } \\
\text { bypass surgery } \\
(n=15)\end{array}$ & $\begin{array}{l}\text { Aortic valve } \\
\text { replacement } \\
(n=10)\end{array}$ & $\begin{array}{l}\text { Mitral valve } \\
\text { replacement } \\
(n=7)\end{array}$ \\
\hline ACK & $2069 \pm 500$ & $3898 \pm 1280$ & $924 \pm 130^{\star}$ \\
ACKMB & $92 \pm 27$ & $214 \pm 93$ & $74 \pm 13$ \\
AHBDH & $448 \pm 124$ & $921 \pm 302$ & $299 \pm 60$ \\
\hline
\end{tabular}

Indicated are mean values $\pm S E M$.

$\star \mathrm{P}<0.05$ compared with aortic valve replacement.

A HBDH (U/I)

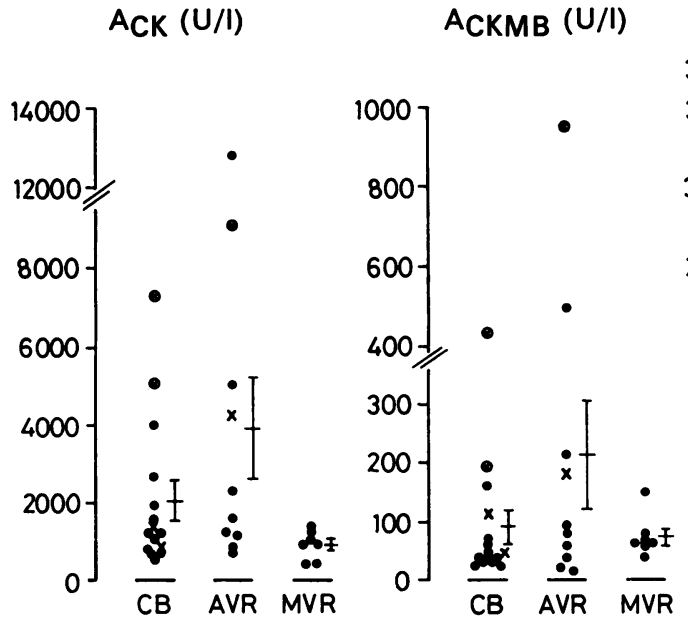


Table 3 Correlation coefficients obtained from linear regression analysis on data of calculated total enzyme release per litre plasma $(A)$ of $C K, C K M B$, and $H B D H$ in patients after cardiac surgery

\begin{tabular}{|c|c|c|c|c|}
\hline & $\begin{array}{l}\text { All patients } \\
(n=32)\end{array}$ & $\begin{array}{l}\text { Coronary } \\
\text { artery bypass } \\
\text { surgery } \\
(n=15)\end{array}$ & $\begin{array}{l}\text { Aortic valve } \\
\text { replacement } \\
(n=10)\end{array}$ & $\begin{array}{l}\text { Mitral valve } \\
\text { replacement } \\
(n=7)\end{array}$ \\
\hline $\begin{array}{c}\text { AckMB vs. } \\
\text { ACK }\end{array}$ & 0.846 & 0.911 & 0.818 & 0.736 \\
\hline$\underset{A_{\text {HBDH }}}{\text { A }_{\text {CKMB }} \text { vs. }}$ & 0.840 & 0.832 & 0.827 & 0.867 \\
\hline $\begin{array}{c}\text { A ABDH vs. } \\
\text { ACK }_{\text {C. }}\end{array}$ & 0.959 & 0.872 & 0.989 & 0.775 \\
\hline
\end{tabular}

together with those of $A_{\mathrm{CK}}$ and $\mathrm{A}_{\mathrm{HBDH}}$, to investigate whether $\mathrm{CK}$ and $\mathrm{HBDH}$ released postoperatively also originate from the myocardium. Table 3 shows the correlation coefficients. In the mitral valve replacement group a relatively low correlation coefficient $(0.736)$ is found, partly because of the low $A$ values in this group of patients (see Figure) and the small number of patients $(n=7)$. Nevertheless, the data in Table 3 seem to indicate a close overall correlation between the $A$ values of the 3 enzymes, showing that the greater part of $\mathrm{CK}$ and HBDH released into the circulation in the postoperative period originated from the heart muscle tissue. The whole range of $A$ values has been divided arbitrarily into 3 parts in order to interpret A values in terms of myocardial damage (Table 4). The lowest range of $A$ values $\left(A_{\mathrm{CK}}<1500 \mathrm{U} / 1\right.$; $A_{\text {CK MB }}<75 \mathrm{U} / 1$; and $A_{\text {HBDH }}<400 \mathrm{U} / 1$ ) represents slight myocardial damage, present in 60 to 73 per cent of the coronary bypass patients, in 30 to 40 per cent of the patients with aortic valve replacement, and in 71 to 100 per cent of the patients with mitral valve replacement, these percentages varying with the enzyme used. Patients in this low range of $A$ values all survived operation and the postoperative period of 1 week. However, a few patients in the coronary bypass group with low A values had new $Q$ waves postoperatively. Since new $Q$ waves are specific indicators of acute myocardial infarction, infarctions may have occurred, which were small in size as concluded from the low values of enzyme release, and had no harmful effect on the postoperative recovery of the patients.

The intermediate range of $A$ values $\left(A_{C K}\right.$ : 1500-3000 U/1; $A_{\text {CK MB }}: 75$ to $150 \mathrm{U} / 1$; and $A_{\text {HBDH }}: 400$ to $800 \mathrm{U} / 1$ ) represents moderate myocardial damage, present in 7 to 20 per cent of the coronary bypass patients, in 20 to 30 per cent of the patients with aortic valve replacement, and in 0 to 29 per cent of the patients with mitral valve replacement, these percentages varying with the enzyme used. Patients in this intermediate range of $A$ values all survived. Only 1 patient in the coronary bypass group with an intermediate $A_{C K M B}$ value showed new $Q$ waves on the electrocardiogram, probably indicating the postoperative development of non-fatal myocardial infarction.

The highest range of $A$ values $\left(A_{C K}>3000 \mathrm{U} / 1\right.$; $A_{\mathrm{CKMB}}>150 \mathrm{U} / 1$; and $\left.A_{\mathrm{HBDH}}>800 \mathrm{U} / 1\right)$ represents extensive myocardial damage, present in 13 to 20 per cent of the coronary bypass patients, the percentage varying with the enzyme used, and in 40 per cent of the patients with aortic valve replacement. None of the patients in the mitral valve replacement group had $A$ values in the highest range.

Postoperative death was associated with the high A values: in the coronary bypass group 67 to 100 per cent of the patients with high A values died, the percentage varying with the enzyme used, and in the aortic valve replacement group 25 per cent of the patients with high $A$ values died. The hearts of these patients all showed extensive recent myocardial infarctions at necropsy. Application of the

Table 4 Comparison of 3 ranges of values of $A_{C K}, A_{C K M B}$, and $A_{H B D H}$ with number of patients, postoperative development of new $Q$ waves in electrocardiogram, and postoperative mortality in 3 surgery groups

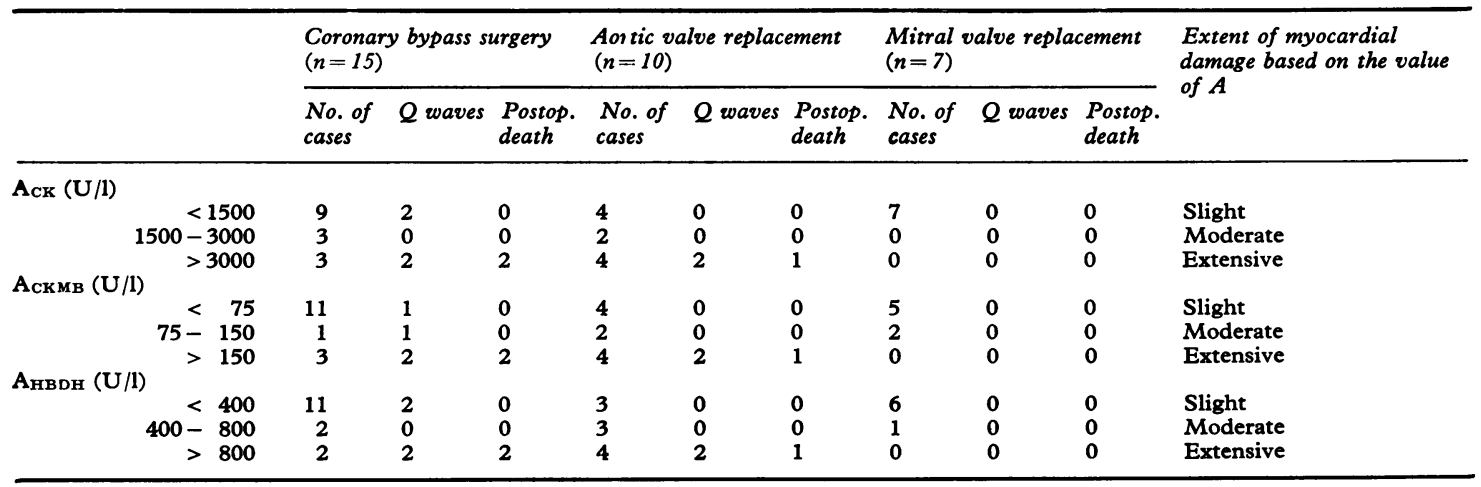


$\chi^{2}$ test on the distribution of non-survivors among the 3 ranges of A values showed a highly significant $(P<0.01)$ association of mortality with the highest range of $A$ values of any of the 3 enzymes. Of the patients in the coronary bypass group having high $A$ values, 67 to 100 per cent showed $Q$ waves postoperatively, dependent on the enzyme used. In the mitral valve replacement group this incidence was 50 per cent. Since $Q$ waves can be found through the whole range of $A$ values and mortality was always associated with the highest range of $\mathbf{A}$ values, it is believed that $A$ values are more relevant than the presence of $Q$ waves in the electrocardiogram to assess the extent of myocardial damage after open-heart surgery. When the ranges (low, intermediate, and high) in $A_{\mathrm{CK}}, A_{\mathrm{CKMB}}$, and $A_{\mathrm{HBDH}}$ were compared for each patient, it was found that in 75 per cent of the cases the 3 ranges were identical (for example, $A_{\mathrm{CK}}$ : low, $A_{\mathrm{CK} \text { mB }}$ : low, and $A_{\mathrm{HBDH}}$ : low). In 25 per cent of the cases the ranges for 2 enzymes were identical, the range for the third enzyme having shifted to a neighbouring category (for example, $A_{C K}$ : low, $A_{C K} M_{B}$ : low, and $A_{\mathrm{HBDH}}$ : intermediate).

Investigations were carried out to see if the maximum plasma level (peak activity) was an equally reliable index of myocardial injury as the calculated $A$ value. Therefore we correlated the peak activities in plasma of $\mathrm{CK}, \mathrm{CKMB}$, and $\mathrm{HBDH}$ corrected for the respective preoperative activities with $A_{\mathrm{CK}}, A_{\mathrm{CK}}$ MB and $A_{\mathrm{HBDH}}$, respectively, in the 3 groups of patients. Table 5 shows the correlation coefficients, which show that for diagnostic purposes one may rely on peak plasma enzyme activities corrected for respective preoperative activities in addition to $\mathrm{A}$ values. The former are obtained more easily than the latter.

The time lapse between the start of the operation and the moment the enzyme reaches its maximal activity in plasma is referred to as peak arrival time of that enzyme. Table 6 shows the peak arrival

Table 5 Correlation coefficients obtained from linear regression analysis on data of calculated total enzyme release per litre plasma $(A)$ and peak* enzyme activity in plasma corrected for preoperative activity, both expressed in $U / l$, in 3 groups of patients

\begin{tabular}{lllll}
\hline & $\begin{array}{l}\text { All patients } \\
(n=32)\end{array}$ & $\begin{array}{l}\text { Coronary } \\
\text { bypass } \\
\text { surgery } \\
(n=15)\end{array}$ & $\begin{array}{l}\text { Aortic valve } \\
\text { replacement } \\
(n=10)\end{array}$ & $\begin{array}{l}\text { Mitral valve } \\
\text { replacement } \\
(n=7)\end{array}$ \\
\hline CK & 0.989 & 0.986 & 0.996 & 0.815 \\
CKMB & 0.962 & 0.974 & 0.957 & 0.982 \\
HBDH & 0.991 & 0.993 & 0.995 & 0.524 \\
\hline
\end{tabular}

*Highest enzyme activity in plasma in the first 24 hours after onset of surgery.
Table 6 Peak arrival times, expressed in hours, of $C K, C K M B$, and $H B D H$ in plasma of 3 groups of patients

\begin{tabular}{llll}
\hline & $\begin{array}{l}\text { Coronary artery } \\
\text { bypass surgery } \\
(n=15)\end{array}$ & $\begin{array}{l}\text { Aortic valve } \\
\text { replacement } \\
(n=10)\end{array}$ & $\begin{array}{l}\text { Mitral valve } \\
\text { replacement } \\
(n=7)\end{array}$ \\
\hline CK & $30.7 \pm 3.0$ & $29.2 \pm 4.8$ & $20.2 \pm 4.0$ \\
CKMB & $12.9 \pm 1.4$ & $12.9 \pm 2.0$ & $6.5 \pm 1.1$ \\
HBDH & $23.2 \pm 3.0$ & $21.1 \pm 2.2$ & $22.8 \pm 6.4$ \\
\hline
\end{tabular}

Indicated are mean values \pm SEM.

times of $\mathrm{CK}, \mathrm{CKMB}$, and $\mathrm{HBDH}$ in the 3 groups of patients. It appears that the peak arrival time of CKMB is significantly shorter in the mitral valve replacement group than in the coronary bypass group $(P<0.01)$ and the aortic valve replacement group $(P<0.01)$. The $A$ values of $C K, C K M B$, and HBDH did not show any significant correlation with aortic cross-clamp time in either of the 3 groups of patients. The same is true for the cardiopulmonary bypass time, except for $A_{\mathrm{CKMB}}(r=0.94)$ and A HBDH $(r=0.80)$ in the mitral valve replacement group.

\section{Discussion}

Acute myocardial infarction is a frequent complication of cardiac surgery, especially when the cardiopulmonary bypass procedure is used. Postoperative electrocardiographic evidence of acute myocardial infarction occurs in 6 to 30 per cent of the patients undergoing aorto-coronary bypass grafting (Hultgren et al., 1971; Bolooki et al., 1972; Alderman et al., 1973; Bolooki et al., 1973; Brewer et al., 1973; Oldham et al., 1973; Espinoza et al., 1974; Ghani et al., 1974; Rose et al., 1974; Codd et al., 1975; Mohiuddin et al., 1976; Codd et al., 1977; Hultgren et al., 1977; Klein et al., 1977; Warren et al., 1977). In patients undergoing valvular replacement 0 to 14 per cent developed electrocardiographic abnormalities characteristic of acute myocardial infarction (Ghani et al., 1974; Rose et al., 1974; Hultgren et al., 1977; Klein et al., 1977). Mortality during aortocoronary bypass grafting and in the postoperative period is reported to be $1 \cdot 1$ to $10 \cdot 7$ per cent (Bolooki et al., 1972; Brewer et al., 1973; Dixon et al., 1973; Oldham et al., 1973; Espinoza et al., 1974; Ghani et al., 1974; Rose et al., 1974; Mohiuddin et al., 1976; Codd et al., 1977; Hultgren et al., 1977; Warren et al., 1977). The mortality in a group of patients who were surgically treated for valvular replacement is 3.9 per cent (Ghani et al., 1974).

The development of new $Q$ waves in the electrocardiogram can be considered a specific, but 
rather insensitive criterion for acute myocardial infarction (Espinoza et al., 1974; Warren et al., 1977). Other criteria sensitive for myocardial injury, either ischaemia or infarction, that can be used are rises in plasma enzymes (Shirey et al., 1970; Hultgren et al., 1971; Alderman et al., 1973; Bolooki et al., 1973; Ghani et al., 1974; Neutze et al., 1974; Rose et al., 1974; Hultgren et al., 1977). More recently, rises in isoenzymes of CK (CKMB) and LDH (LDH-1) in plasma are used for the diagnosis of myocardial injury (Dixon et al., 1973; Oldham et al., 1973; Codd et al., 1975; Mohiuddin et al., 1976; Pyle et al., 1976; Codd et al., 1977; Warren et al., 1977). Both CKMB and LDH-1 are raised in myocardial infarction, or more generally in myocardial injury. In patients with acute myocardial infarction admitted to the coronary care unit plasma enzymes and isoenzymes have not only provided the clinician with a means to diagnose acute myocardial infarction, but also with a method to assess the size of the infarct (Sobel et al., 1972; Witteveen et al., 1975).

Infarct sizes of patients having acute myocardial infarction in the coronary care unit showed good correlation with prognosis (Sobel et al., 1972; Norris et al., 1975), functional class according to the NYHA criteria (Sobel et al., 1972), the presence of pulmonary venous congestion or pulmonary oedema (Norris et al., 1975), left ventricular haemodynamics (Mathey et al., 1974; Rogers et al., 1977), and incidence of ventricular arrhythmias (Roberts et al., 1975b).

In this study we investigated patients who underwent cardiac surgery with the aid of extracorporeal circulation. The calculated amounts of $\mathrm{CK}, \mathrm{CKMB}$, and $\mathrm{HBDH}$ released postoperatively by the heart into the circulation showed good correlations with each other (Table 3), with mortality (Table 4), and with peak plasma activities of $\mathrm{CK}, \mathrm{CKMB}$, and $\mathrm{HBDH}$, respectively (Table 5).

The relation between postoperative plasma enzyme or isoenzyme activity and duration of cardiopulmonary bypass as well as total aortic crossclamping time was established earlier in patients receiving aortocoronary bypass grafts and valvular replacement (Oldham et al., 1973; Ghani et al., 1974; Neutze et al., 1974; Codd et al., 1975; Pyle et al., 1976). However, except for the patients undergoing mitral valve surgery, no significant correlation was found between cardiopulmonary bypass time and $\mathrm{A}$ values. No correlation was observed between aortic cross-clamping time and $A$ values in either group of patients. The A values for $\mathrm{CK}$ in patients of the aortic valve replacement group were significantly higher $(P<0.05)$ than those in patients of the mitral valve replacement group.
Table 7 Peak arrival times, expressed in hours, of $C K, C K M B$, and $H B D H$ in patients who underwent coronary artery bypass surgery and in patients with acute myocardial infarction admitted to coronary care unit $(C C U)$

\begin{tabular}{llll}
\hline & Surgery & $\begin{array}{l}\text { Acute myocardial } \\
\text { infarction in CCU }\end{array}$ & $P$ \\
\hline CK & $30.7 \pm 3.0(15)$ & $\begin{array}{l}22.9 \pm 1.7(10) \\
\text { (Witteveen et al., 1975) }\end{array}$ & $<0.05$ \\
CKMB & $12.9 \pm 1.4(15)$ & $\begin{array}{l}18 \cdot 0 \pm 0.5(31) \\
\text { (Fiolet et al., 1977) }\end{array}$ & $<0.01$ \\
HBDH & $23.2 \pm 3.0(15)$ & $\begin{array}{l}39 \cdot 1 \pm 2.2(10) \\
\text { (Witteveen et al., 1975) }\end{array}$ & $<0.01$ \\
\hline
\end{tabular}

Indicated are mean values $\pm S E M$; number of patients is indicated in parentheses. P: surgery vs. acute myocardial infarction.

Associated with this difference is a longer cardiopulmonary bypass period in the aortic valve replacement group (156.4 min) compared with that in the mitral valve replacement group (119.6 $\mathrm{min}$ ), though this difference was not significant. Peak arrival time of CKMB was significantly longer in the patients of the aortic valve replacement group (12.9 hour) than in the patients of the mitral valve replacement group (6.5 hour) $(P<0.01)$ (Table 6$)$. An explanation for these differences between the valvular replacement groups is probably given by the hypertrophied state of the hearts in the aortic valve replacement group. In these hypertrophied hearts, whether concentric or dilated, the selective perfusion of the coronary arteries during the period of cardiopulmonary bypass may be inadequate in perfusing the subendocardial layers of the heart. As cardiopulmonary bypass lasts for an average of 156 minutes, this period may be long enough to promote the development of extensive subendocardial ischaemia, leading to a considerable amount of enzyme released before and directly after disconnection of extracorporeal circulation.

As shown in Table 7, the peak arrival times of $\mathrm{CKMB}$ and $\mathrm{HBDH}$ are earlier after surgery than after acute myocardial infarction, while for CK the reverse is true. The same phenomenon was apparent from inspection of the release curves, that is the time derivative of the quantity $\mathrm{A}$. While the release of enzyme after acute myocardial infarction usually lasts for at least 48 hours (Witteveen et al., 1975), the release of CKMB and HBDH was completed within 24 hours after operation in the majority of cases, while the release of $\mathrm{CK}$ continued for more than 60 hours. This observation strongly suggests a prolonged leakage of $\mathrm{CK}$ from damaged skeletal muscle after surgery. The earlier appearance of cardiac enzymes after surgery, compared with acute myocardial infarction, has been described as a washout phenomenon after reflow of ischaemic myocardium (Jarmakani et al., 1976; Maroko and 
Vatner, 1977). As a consequence of these findings the calculation of A was restricted to the first 24 hours after operation in order to ensure that myocardial enzyme release was studied. As skeletal muscle contributes late to the $\mathrm{CK}$ activity in plasma, the $\mathrm{CK}$ release during the first 24 hours will be mainly from the heart; this explains the high correlations of $A_{C K}$ with $A_{C K M B}$ and $A_{\mathrm{HBDH}}$ (Table 3).

Of the 3 enzymes used in this study CKMB and $\mathrm{HBDH}$ are most appropriate for the calculation of the total amount of enzyme released by the injured heart into the circulation. As the chromatographic separation of CKMB is a time-consuming procedure, especially if many plasma samples have to be assayed, the use of $\mathrm{HBDH}$ is preferred to that of CKMB. Only when moderate or severe haemolysis is present in the plasma samples, is CKMB the enzyme of choice for recognition and quantification of myocardial injury after cardiac surgery.

We thank Professor A. C. Arntzenius for revising the manuscript.

\section{References}

Alderman, E. L., Matlof, H. J., Shumway, N. E., and Harrison, D. C. (1973). Evaluation of enzyme testing for the detection of myocardial infarction following direct coronary surgery. Circulation, 48, 135-140.

Bolooki, H., Sommer, L., Cunha, D., and Ghahramani, A. (1972). Complications of coronary bypass surgery (abstract). Circulation, 45 and 46, Suppl. II, 69.

Bolooki, H., Sommer, L., Faraldo, A., Ghahramani, A., Slavin, D., and Kaiser, G. A. (1973). The significance of serum enzyme studies in patients undergoing direct coronary artery surgery. Fournal of Thoracic and Cardiovascular Surgery, 65, 863-868.

Brewer, D. L., Bilbro, R. H., and Bartel, A. G. (1973). Myocardial infarction as a complication of coronary bypass surgery. Circulation, 47, 58-64.

Codd, J. E., Kaiser, G. C., Wiens, R. D., Barner, H. B., and Willman, V. L. (1975). Myocardial injury and bypass grafting. Value of serum enzymes in diagnosis. Fournal of Thoracic and Cardiovascular Surgery, 70, 489-494.

Codd, J. E., Sullivan, R. G., Weins, R. D., Barner, H. B., Kaiser, G. C., and Willman, V. L. (1977). Myocardial injury following myocardial revascularization. Detection by isoenzyme analysis. Circulation, 55 and 56, Suppl. II, 49-53.

Dixon, S. H., jun, Limbird, L. E., Roe, C. R., Wagner, G. S., Oldham, H. N., jun, and Sabiston, D. C., jun (1973). Recognition of postoperative acute myocardial infarction. Application of isoenzyme techniques. Circulation, 47 and 48, Suppl. III, 137-140.

Espinoza, J., Lipski, J., Litwak, R., Donoso, E., and Dack, S. (1974). New $Q$ waves after coronary artery bypass surgery for angina pectoris. American fournal of Cardiology, 33, 221-224.

Fiolet, J. W. T., Willebrands, A. F., Lie, K. I., and Ter Welle, H. F. (1977). Determination of creatine kinase isoenzyme MB (CK-MB): comparison of methods and clinical evaluation. Clinica Chimica Acta, 80, 23-35.
Ghani, M. F., Parker, B. M., and Smith, J. R. (1974). Recognition of myocardial infarction after cardiac surgery and its relation to cardiopulmonary bypass. American Heart fournal, 88, 18-22.

Hultgren, H. N., Miyagawa, M., Buck, W., and Angell, W. W. (1971). Ischemic myocardial injury during coronary artery surgery. American Heart fournal, 82, 624-631.

Hultgren, H. N., Shettigar, U. R., Pfeifer, J. F., and Angell, W. W. (1977). Acute myocardial infarction and ischemic injury during surgery for coronary artery disease. American Heart fournal, 94, 146-153.

Jarmakani, J. M., Limbird, L., Graham, T. C., and Marks, R. A. (1976). Effect of reperfusion on myocardial infarct, and the accuracy of estimating infarct size from creatine phosphokinase in the dog. Cardiovascular Research, 10, 245-253.

Klein, M. S., Coleman, R. E., Weldon, C. S., Sobel, B. E., and Roberts, R. (1977). Concordance of electrocardiographic and scintigraphic criteria of myocardial injury after cardiac surgery. Fournal of Thoracic and Cardiovascular Surgery, 71, 934-937.

Konttinen, A., and Somer, H. (1972). Determination of serum creatine kinase isoenzymes in myocardial infarction. American fournal of Cardiology, 29, 817-820.

Maroko, P. R., and Vatner, S. F. (1977). Altered relationship between phosphokinase and infarct size with reperfusion in conscious dogs. Fournal of Molecular Medicine, 2, 309-315.

Mathey, D., Bleifeld, W., Hanrath, P., and Effert, S. (1974). Attempt to quantitate relation between cardiac function and infarct size in acute myocardial infarction. British Heart fournal, 36, 271-279.

Mercer, D. W., and Varat, M. A. (1975). Detection of cardiacspecific creatine kinase isoenzyme in sera with normal or slightly increased total creatine kinase activity. Clinical Chemistry, 21, 1088-1092.

Mohiuddin, S. M., Raffetto, J., Sketch, M. H., Lynch, J. D., Schultz, R. D., and Runco, V. (1976). LDH isoenzymes and myocardial infarction in patients undergoing coronary bypass surgery: an excellent correlation. American Heart fournal, 92, 584-588.

Neutze, J. M., Drakeley, M. J., Barratt-Boyes, B. G., and Hubbert, K. (1974). Serum enzymes after cardiac surgery using cardiopulmonary bypass. American Heart fournal, 88, 425-442.

Norris, R. M., Whitlock, R. M. L., Barratt-Boyes, C., and Small, C. W. (1975). Clinical measurement of myocardial infarct size. Modification of a method for the estimation of total creatine phosphokinase release after myocardial infarction. Circulation, 51, 614-620.

Oldham, H. N., jun, Roe, C. R., Young, W. G., jun, and Dixon, S. H., jun (1973). Intraoperative detection of myocardial damage during coronary artery surgery by plasma creatine phosphokinase isoenzyme analysis. Surgery, 74, 917-924.

Oliver, I. T. (1955). A spectrophotometric method for the determination of creatine phosphokinase and myokinase. Biochemical fournal, 61, 116-122.

Pyle, R. B., Blomberg, D. J., Burke, M. D., Lindsay, W. G., and Nicoloff, D. M. (1976). CPK-MB isoenzyme: use in diagnosis of acute myocardial infarction in the early postoperative period. Fournal of Thoracic and Cardiovascular Surgery, 71, 884-890.

Roberts, R., Gowda, K. S., Ludbrook, P. A., and Sobel, B. E (1975a). Specificity of elevated serum MB creatine phosphokinase activity in the diagnosis of acute myocardial infarction, American fournal of Cardiology, 36, 433-437.

Roberts, R., Husain, A., Ambos, H. D., Oliver, G. C., Cox, J. R., jun, and Sobel, B. E. (1975b). Relation between infarct size and ventricular arrhythmia. British Heart fournal, 37, 1169-1175. 
Roe, C. R., Limbird, L. E., Wagner, G. S., and Nerenberg, S. T. (1972). Combined isoenzyme analysis in the diagnosis of myocardial injury: application of electrophoretic methods for the detection and quantitation of the CPK-MB isoenzyme. Fournal of Laboratory and Clinical Medicine, 80, 577-590.

Rogers, W. J., McDaniel, H. G., Smith, L. R., Mantle, J. A., Russell, R. O., jun, and Rackley, C. E. (1977). Correlation of angiographic estimates of myocardial infarct size and accumulated release of creatine kinase $M B$ isoenzyme in man. Circulation, 56, 199-205.

Rosalki, S. B., and Wilkinson, J. H. (1960). Reduction of $\alpha$-ketobutyrate by human serum. Nature (London), 188, 1110-1111.

Rose, M. R., Glassman, E., Isom, O. W., and Spencer, F. C. (1974). Electrocardiographic and serum enzyme changes of myocardial infarction after coronary artery bypass surgery. American fournal of Cardiology, 33, 215-220.

Shirey, E. K., Proudfit, W. L., and Sones, F. M., jun (1970). Serum enzyme and electrocardiographic changes after coronary artery surgery. Correlation with selective cine coronary arteriography and left ventriculography. Chest,
57, 122-130.

Sobel, B. E., Bresnahan, G. F., Shell, W. E., and Yoder, R. D. (1972). Estimation of infarct size in man and its relation to prognosis. Circulation, 46, 640-648.

Warren, S. G., Wagner, G. S., Bethea, C. F., Roe, C. R., Oldham, H. N., and Kong, Y. (1977). Diagnostic and prognostic significance of electrocardiographic and CPK isoenzyme changes following coronary bypass surgery: correlation with findings at one year. American Heart Fournal, 93, 189-196.

Witteveen, S. A. G. J., Hemker, H. C., Hollaar, L., and Hermens, W. Th. (1975). Quantitation of infarct size in man by means of plasma enzyme levels. British Heart fournal, 37, 795-803.

Requests for reprints to $\mathrm{Dr} A$. van der Laarse, Laboratory of Cardiobiochemistry, Building 20, University Hospital Leiden, Rijnsburgerweg 10, Leiden, The Netherlands. 